Innlegg på inntil 400 ord lastes opp i http://mc.manuscriptcentral.com/tidsskriftet.

Redaksjonen forbeholder seg retten til å foreta redaksjonelle endringer.

Forfattere av vitenskapelige artikler har tilsvarsrett (jf. Vancouver-gruppens regler).

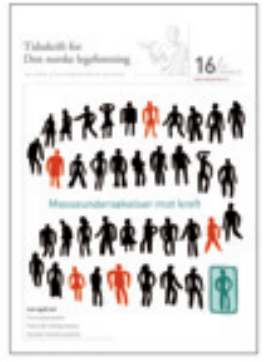

\section{Hvilken kunnskap om kunnskapen?}

Takk til Jan C. Frich \& Per Olav Vandvik (1) og til Per Olav Vandvik og medarbeidere (2) for deres tilsvar i Tidsskriftet $\mathrm{nr}$. 16/2011 og 17/2011 til min kommentarartikkel om styrker og fallgruver i evidensbasert medisin (3). Jeg er glad for at artikkelen vekker debatt - det var hensikten!

Jeg kan berolige Frich \& Vandvik (1) med at forslaget til eksamensoppgave som jeg harselerte over (og som aldri ble brukt), ikke kom fra faget Kunnskapshåndtering, ledelse og kvalitetsforbedring (KLoK), der de har en sentral rolle, men fra et klinisk miljø der man åpenbart hadde forlest seg på dogmatisk vulgærcochranisme. Det er også beklagelig hvis jeg har valgt en uheldig illustrasjon av «evidenspyramiden» - selv om akkurat denne versjonen finnes i tallrike utgaver på nettet.

Mitt hovedanliggende var å problematisere det kunnskapssyn som eksplisitt nedvurderer erfaringsbasert kunnskap og kunnskap fremkommet gjennom andre forskningsmetoder enn randomiserte studier. Det er gledelig å erfare at ledende representanter for Kunnskapssenteret også arbeider for et sunt samspill mellom ulike kilder til kunnskap (2). Dermed skulle det være god mulighet til å danne en motvekt mot de mange vulgariserte versjonene av evidensbasert medisin som florerer.

Det er samtidig fristende å utfordre representantene både for KLoK-faget (1) og for Kunnskapssenteret (2) til å fortelle hvordan de lærer studenter, helsepersonell og helsebyråkrater å forholde seg kritisk og fleksibelt til relevante kunnskapskilder avhengig av den aktuelle kliniske konteksten. Frich \& Vandvik (1) legger listen høyt når de kaller sitt innlegg Kunnskap om kunnskapen (1). Dette er emnet for den filosofiske disiplinen epistemologi - læren om viten og erkjennelse. En grundigere undervisning i epistemologi i medisinstudiet ville sannsynligvis være gunstig og demme opp for så vel vulgærcochranisme som for vulgær anticochranisme (som også finnes) og andre erkjennelsesteoretiske lettvintheter. Men seriøs epistemologi er åpenbart noe ganske annet og mer grunnleggende enn å kunne ramse opp de leksikalske kriteriene for å plassere en klinisk anbefaling i nivåer som I, II-1, II-2 eller liknende, slik det konvensjonelt gjøres i evidensbaserte retningslinjer. Ut fra debattantenes gode ansatser og gode faglige forutsetninger er jeg derfor spent og nysgjerrig på hvordan de benytter KLoK-fagets og Kunnskapssenterets samlede ressurser til å gi grunnleggende kunnskap om kunnskapen.

\section{Torgeir Bruun Wyller}

t.b.wyller@medisin.uio.no

Geriatrisk avdeling

Oslo universitetssykehus

Torgeir Bruun Wyller (f. 1960) er dr.med., spesialist $\mathrm{i}$ indremedisin og i geriatri, professor i geriatri ved Universitetet i Oslo og overlege ved Geriatrisk avdeling, Oslo universitetssykehus. Han har deltatt i planleggingen og gjennomføringen av flere randomiserte, kontrollerte undersøkelser.

Oppgitte interessekonflikter: Forfatterens forskningsgruppe har mottatt forelesningshonorar fra Pfizer, AstraZeneca, Nycomed og Roche.

\section{Litteratur}

1. Frich JC, Vandvik PO. Kunnskap om kunnskapen. Tidsskr Nor Legeforen 2011; 131: 1540.

2. Vandvik PO, Eiring $\varnothing$. Jamtvedt $G$ et al. Ja til kunnskapsbasert praksis. Tidsskr Nor Legeforen 2011; 131: 1637-8. (17/11)

3. Wyller TB. Evidensbasert medisin eller vulgærcochranisme? Tidsskr Nor Legeforen 2011; 131 $1181-2$.

\section{Vulgærcochranisme i praksis}

Vi takker Geir W. Jacobsen for hans innspill (1) til våre artikler om hhv. perkutan innsetting av kunstig pulmonalklaff (2) og om styrker og svakheter ved evidensbasert medisin (3). Jacobsen har rett $\mathrm{i}$ at de to artiklene gjerne kan ses i sammenheng, og vi synes Stein A. Evensens kraftige angrep på pulmonalklaffartikkelen nærmer seg en illustrasjon av vulgærcochranisme i praksis (4).

Det er ingen uenighet om at randomiserte og kontrollerte undersøkelser som regel har en rekke metodologiske fortrinn ved evaluering av behandlingsmetoder. Men det betyr ikke at andre kilder til kunnskap kan forkastes, slik vulgærcochranismen gjør.
Både erfaringsbasert kunnskap og undersøkelser utført med annen metodologi, f.eks. pasientserier, kasuistikker og kvalitative studier, gir innsikt i virkeligheten.

Generelt er det minst to mulige grunner til ikke å gjennomføre en randomisert studie. Den første er at en slik studie ville være praktisk ugjennomførbar, f.eks. fordi den aktuelle tilstanden er for sjelden, den andre at en slik studie vil være uetisk fordi det $\mathrm{i}$ utgangspunktet er sterk grunn til å tro at en gitt behandling er bedre enn alternativet - fallskjermeksemplet (5) har gyldighet for en rekke kliniske tilstander. Det kan selvsagt være vanskelig å vurdere om disse argumentene har gyldighet i et gitt tilfelle, og en slik vurdering må gjøres transparent og må kunne tåle kritikk. Men ved å avvise problemstillingen påtar man seg et betydelig ansvar. I løpet av de siste 50 år er for eksempel dødeligheten ved komplekse medfødte hjertefeil sunket fra nær $100 \%$ til et par prosent, så å si uten at det er foretatt en eneste randomisert studie. Jacobsen mener de kirurger og intervensjonskardiologer som har promovert denne utviklingen, skylder å bevise nytten av sin behandling (1). Vi mener bevisbyrden er motsatt.

Jacobsen kritiserer også at fagutviklingen foregår «etter eget forgodtbefinnende». Finner han det problematisk at klinikere, etter grundig vurdering av evidensgrunnlaget, tar en selvstendig beslutning om hva slags behandling som bør tilbys pasienten? I så fall er vi grunnleggende uenige - vi mener at det nettopp er slike vurderinger som gjør oss til leger.

\section{Vegard Bruun Wyller}

Barnemedisinsk avdeling

Torgeir Bruun Wyller

Geriatrisk avdeling

Oslo universitetssykehus

Vegard Bruun Wyller (f. 1972) er dr.med., spesialist i pediatri, førsteamanuensis i pediatri ved Universitetet i Oslo og overlege ved Barnehjerteseksjonen. Han har deltatt i planleggingen og gjennomføringen av flere randomiserte, kontrollerte undersøkelser.

Ingen oppgitte interessekonflikter.

Torgeir Bruun Wyller (f. 1960) er dr.med., spesialist i indremedisin og i geriatri, professor i geriatri ved Universitetet i Oslo og overlege ved Geriatrisk avdeling. Han har deltatt i planleggingen og gjennomføringen av flere randomiserte, kontrollerte undersøkelser. 
Oppgitte interessekonflikter: Forfatteren har mottatt forelesningshonorar fra Pfizer, AstraZeneca, Nycomed og Roche, som alt er overført til hans forskningsgruppe.

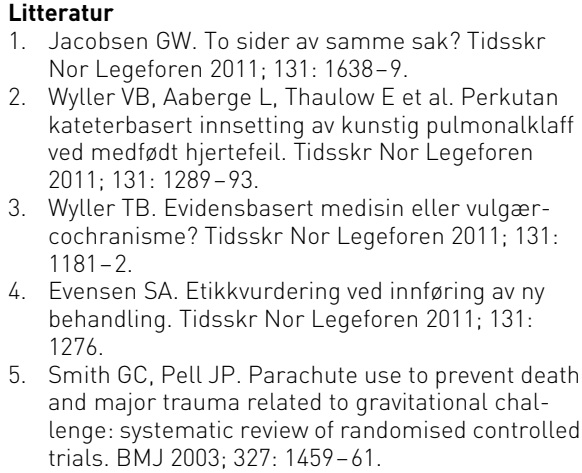

3. Wyller TB. Evidensbasert medisin eller vulgærcochranisme? Tidsskr Nor Legeforen 2011; 131 $1181-2$

4. Evensen SA. Etikkvurdering ved innføring av ny behandling. Tidsskr Nor Legeforen 2011; 131: 1276.

5. Smith GC, Pell JP. Parachute use to prevent death and major trauma related to gravitational challenge: systematic review of randomised controlled trials. BMJ 2003; 327: 1459-61.

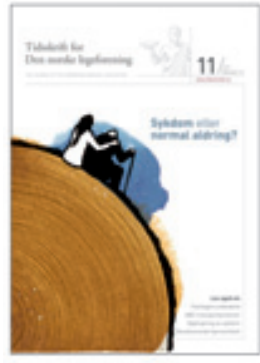

\section{Systemfeil \\ i norsk helsevesen}

I redaktørens leder i Tidsskriftet nr. 11/2011 påpekes det at systemfeil bør kunne forebygges (1). I den senere tid har det også i dagspressen vært pekt på at helsevesenet har IT-problemer som truer pasientsikkerheten (2).

Det kan se ut som at viljen og evnen til å innrømme feil, for så gjøre noe med dem, er begrenset. Det kan være både administrative og økonomiske årsaker til at systemfeil opprettholdes. Men i siste instans har legene selv et stort ansvar for å identifisere, påpeke og gjennomføre kvalitets- og sikkerhetsarbeid.

Jeg vil spesielt nevne en uheldig rutine som har vært utbredt så lenge jeg har arbeidet som lege.

Når en prøve tas, gis ofte beskjeden: «Dersom du ikke hører noe, er alt i orden.» Dette gjøres til tross for at rekvirenten ikke fører logg over utførte prøver. Dermed kan svar som handler om liv og død, f.eks. melanom uten fri rand, forsvinne i posten, på laboratoriet eller nå i den elektroniske journalen. I verste fall blir forsvinningen ikke oppdaget før pasienten har fått symptomgivende metastaser.

På samme måte er henvisninger eller innkallinger til sykehus blitt borte fordi forsendelsene ikke har vært loggført og fulgt opp. Dersom pasienten selv var blitt bedt om å passe på, kunne mye tid vært spart, og sykdommen kunne blitt behandlet før det var for sent.

Jeg mener det må være en selvfølge at pasientene alltid skal få et svar når det er tatt en prøve, spesielt ved biopsier. Dersom de ikke hører noe i løpet av 2-3 uker, skal de etterlyse svaret. Dette bør de få klar beskjed om. Ved henvisninger til poliklinikk eller sykehus bør også pasienten bli bedt om å kontakte institusjonen eller rekvirenten dersom de ikke făr respons innen en viss tid, eventuelt bør de også få med seg kopi av henvisningen til konsultasjonen. Det siste kan være tidsbesparende fordi man unngår leting etter henvisningsskriv som er kommet på avveie.

På bakgrunn av det ovennevnte vil jeg oppfordre alle kolleger til å informere pasientene om at enhver prøve eller henvisning betinger et svar til dem personlig innen en viss tidsfrist.

Slike rutiner kan styrke lege-pasient-relasjonen. Og man kan unngå at et lite uhell, en feil i postgangen eller på laboratoriet eller en forglemmelse på legekontoret får en unødvendig og alvorlig konsekvens.

\section{Jon Langeland \\ Oslo}

Jon Langeland (f. 1951) er hudlege og ansvarlig lege ved Hudklinikken, Oslo.

Ingen oppgitte interessekonflikter.

\section{Litteratur \\ 1. Haug C. Feil og læring. Tidsskr Nor Legeforen 2011; 131: 1061. \\ 2. Endresen R. Slår alarm om it-svikt. Dagens Næringsliv 4.6. 2011: $20-1$}

\section{Slagsentre og dødelighet}

I Tidsskriftet nr. 11/2011 hevdes det med referanse til en artikkel i JAMA at «slagsentre gir lavere dødelighet» (1). Den absolutte reduksjonen var på 2,5\%. Den som leser artikkelen i JAMA, vil imidlertid se at det var store forskjeller i de demografiske dataene for slagsentrene og «ikke-designerte slagsentre» (2). Forskjellene var spesifikke for slag, for forskerne fant ingen forskjell i dødelighet når det gjaldt gastrointestinale blødninger og hjerteinfarkt mellom de samme enhetene. Pasienten som ble innlagt i slagsentre med lavere dødelighet var signifikant yngre og hadde høyere årsinntekt, det var en annen etnisk gruppeinndeling, annen forsikringsdekning, mindre komorbide tilstander etc. Forfatterne gjør store anstrengelser for å korrigere for alle forskjellene statistisk, og de gjør dette på en overbevisende måte. Imidlertid sitter man til slutt igjen med tanken om at det kan være seleksjonsskjevhet som gir de gode resultatene.
Det er rent intuitivt riktig at slagsentre gir mer optimal behandling enn andre sentre. For meg blir imidlertid uttalelsen fra overlege Christian G. Lund ved Rikshospitalet om at Norge snarest mulig må sentralisere behandlingen av akutt cerebral sirkulasjonssvikt fullstendig gal. Det riktige må etter min mening være å desentralisere tjenesten ved å oppgradere behandlingen på så mange steder som mulig for at det skal gå kort tid før pasientene får behandling. Vi kan ikke transportere disse pasientene land og strand rundt til høyspesialiserte sentre da vil vi tape tid mens hjernevevet dør.

Dette forsto vi i kardiologien for mange år siden, da vi på Lillehammer startet med streptokinase ved hjerteinfarkt langt utenfor sykehus i samarbeid med luftambulansen i 1980-årene. I tillegg til et EKG trenger man en CT-undersøkelse ved hjerneslag. Trenger man tolkingshjelp, kan man få dette på få minutter etter elektronisk overføring. Kunnskapen er tilgjengelig og bør benyttes overalt hvor det er mulig. Som eksempel må det være feil politikk å frakte pasienter fra Gjøvik til Lillehammer for akutt slagbehandling. Sykehuset på Gjøvik må selvsagt gi den standardiserte behandlingen som er nødvendig. Det er altså desentralisering - ikke sentralisering - som må til. Indikasjonene for de høyspesialiserte operative behandlingene får man lære seg, slik at enkelte pasienter får nytte av Rikshospitalets ekspertise.

\section{Morten Grundtvig}

Lillehammer

\section{Morten Grundtvig (f. 1947) er seksjonsoverlege} ved Avdeling for indremedisin ved Sykehuset Innlandet Lillehammer og spesialist i hjertesykdommer og i indremedisin. Ingen oppgitte interessekonflikter.

Litteratur

1. Brean A. Slagsentre gir lavere dødelighet. Tidsskrift Nor Legeforen 2011 2011; 131: 1067.

2. Xian Y, Holloway R, Chan PS et al. Association between stroke center hospitalization for acute ischemic stroke and mortality. JAMA 2011; 305 373-80.

\section{Faglig reflekterende, ikke populistisk}

I Tidsskriftet nr. 8/2011 blir Trond Aarres bok Manifest for psykisk helsevern omtalt under overskriften Populistisk om psykiatritjenesten (1). Hvorfor er denne overskriften valgt? Populisme er ikke noe honnørord, det betyr at man opportunistisk hevder synspunkter som er populære blant folk.

Anmelderen bruker uttrykket «populistisk fremstilling» når han omtaler Aarres redegjørelse for bruk av tvang, og han hevder boken egentlig inneholder lite nytt. Han avslutter imidlertid med å si at den er 